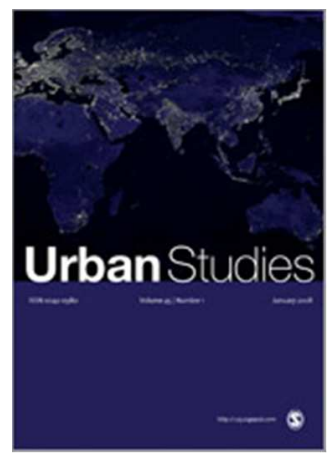

\title{
Cities and the Anthropocene: Urban Governance for the New Era of Regenerative Cities.
}

\begin{tabular}{|r|l|}
\hline Journal: & Urban Studies \\
\hline Manuscript ID & CUS-867-17-10.R1 \\
\hline $\begin{array}{r}\text { <b>Discipline: Please select a } \\
\text { keyword from the following list } \\
\text { that best describes the } \\
\text { discipline used in your paper.: }\end{array}$ & Planning \\
\hline $\begin{array}{r}\text { World Region: Please select } \\
\text { the region(s) that best reflect } \\
\text { the focus of your paper. }\end{array}$ & \\
$\begin{array}{r}\text { Names of individual countries, } \\
\text { cities \& economic groupings } \\
\text { should appear in the title } \\
\text { where appropriate.: }\end{array}$ & Australia, Southeast Asia \\
\hline $\begin{array}{r}\text { Major Topic: Please identify up } \\
\text { to } 5 \text { topics that best identify } \\
\text { the subject of your article.: }\end{array}$ & $\begin{array}{l}\text { Agglomeration/Urbanisation, Built Environment, } \\
\text { Environment/Sustainability, Infrastructure, Planning }\end{array}$ \\
\hline $\begin{array}{r}\text { You may add up to } 2 \text { further } \\
\text { relevant keywords of your } \\
\text { choosing below:: }\end{array}$ & Regenerative Cities \\
\hline
\end{tabular}




\title{
Cities and the Anthropocene: Urban Governance for the New Era of Regenerative Cities
}

\begin{abstract}
The emerging "grand challenges" of climate change, resource scarcity and population growth present a risk nexus to cities in the Anthropocene. This paper discusses the potential that rapid urbanization presents to help mitigate these risks through large-scale transitions if future urban development is delivered using evidence-based policies that promote regenerative urban outcomes (e.g. decarbonizing energy, recycling water and waste, generating local food, reclaiming areas for biodiversity). Observations from an Australian case study are used to describe urban governance approaches capable of supporting regenerative urbanism.

The regenerative urbanism concept is associated with macro-scale urban and transport planning that shape different urban fabrics (walking, transit, automobile urban fabric) as the underlying infrastructure of each fabric exhibits different performance, with automobile fabric being the least regenerative. Supporting urban systems based upon regenerative design principles at different scales (macro, meso and micro) can deliver deep and dramatic outcomes for not just reducing impact from the grand challenges but turning them into regenerative change. In combination, these approaches form the cornerstone of regenerative cities that can address the grand challenges of the Anthropocene, while simultaneously improving liveability and urban productivity to foster human flourishing.
\end{abstract}

\section{Keywords:}

Regenerative cities, Anthropocene, regenerative design, urban governance, urban fabrics, urban transitions. 


\section{Introduction}

Once constructed, urban environments can be slow to change. Buildings typically last for decades and infrastructure such as roads and pipes can last for centuries. Therefore, urban structures should be designed, not only to meet the needs of today, but ideally to meet the social, environmental and economic needs of the long-term future.

However, the long-term future is increasingly uncertain. The world is currently undergoing a period of rapid change, ecologically, socially and economically. Rapid change and uncertainty are associated with the so-called "grand challenges" of climate change, resource scarcity, population growth and social inequity (Bina et al. 2016). The uncertainties presented by the grand challenges tend to be polarizing and lend themselves to fostering fear (Newman et al, 2017); but in times of fear, positive narratives can generate momentum for collective action to deliver a hopeful future (Inayatullah and Milojević 2015). Regenerative cities offer such a narrative.

In keeping with this special issue on Environmental Governance for Urban Resilience in the Asia-Pacific, this paper makes reference to a case study from Australia. Australia is a nation where $89 \%$ of the population live in cities, making it one of the most urbanized nations in the world. As developing countries in the Asia Pacific region urbanize, they can perhaps learn from the successes and failures of rapid urbanization as witnessed in Australia and even from new demonstrations taking urban development into a regenerative phase as outlined in this paper. 
A major topic of consideration in recent years has been the carrying capacity of the planet in light of human impact and the ability of the biosphere to regenerate and to absorb wastes at a pace equal or greater to the pace that resources are used and pollutants generated (Rees and Wackernagel 2008, Rockström et al. 2009; Steffen, Richardson, et al. 2015). The ubiquitous impact of humans upon the biosphere is encapsulated in the term - the Anthropocene (Baccini \& Brunner, 2012; Crutzen, 2002; Crutzen \& Stoermer, 2000; Ruddiman, Ellis, Kaplan, \& Fuller, 2015; Steffen et al., 2011; Steffen, Broadgate, Deutsch, Gaffney, \& Ludwig, 2015; Steffen, Crutzen, \& McNeill, 2007; Whitmee et al., 2015; Zalasiewicz, Williams, Steffen, \& Crutzen, 2010).

Although arguments exist for recognition of the Anthropocene as a legitimate geologic epoch (Waters et al., 2016) this designation is still under debate by the various supporting committees and the ultimate authority on geologic time scales, the International Society of Geologic Sciences (see: Zalasiewicz, Waters, Head, \& Castree, 2017). Never-the-less, the use of the term Anthropocene has become synonymous with the threat posed by human activity to planetary systems. Recent writers such as Bonneuil \& Fressoz (2016) suggest that, rather than focus on geologic nomenclature, the usefulness of the term Anthropocene is in the opportunity it provides as a way to "rethink our visions of the world" and frame various future oriented narratives (Bonneuil \& Fressoz, 2016 p.12). This paper explores the positive future oriented narrative of regenerative cities. 
Numerous dates have been suggested for the commencement of the Anthropocene, including the emergence of agriculture and cities around 10,000 years ago, the colonization of America, or the beginning of the industrial revolution (Bonneuil \& Fressoz 2016); but a recent review by Steffen, Broadgate, et al. (2015) suggests a revised start date, around 1945, to coincide with the detonation of the atomic bomb and the exponential resource use driven by rapid industrial, population and economic growth post-WWII based on fossil fuels. This period marks the beginning of the so called 'great acceleration', a concept described in some detail by Steffen, Broadgate et al. (2015). This post-WWII, period also witnessed the wholehearted embrace of Modernist planning and transport agendas in western society, which had been evolving in the Europe and the US over the previous decades (Newman et al, 2017).

If we take 1945 to mark the start of the Anthropocene; then the Anthropocene is synchronous with this widespread uptake of Modernist planning and transportation ideals. This paper addresses the narrative of the Anthropocene as applied to urban planning and the creation of a planning regime being framed to address the failings of this Modernist approach.

Narratives are critically important to urban governance, because it is narratives that form the norms and values of society which, in turn, impact the governance models that shape cities. Over just a few decades in mid to late 20th Century, a dominant Modernist narrative infiltrated all aspects of western society. This paper demonstrates how these values have resulted in unsustainable cities, and conversely, how the adoption of a new regenerative narrative, could shape new regimes and governance models that could support a new era of regenerative cities. 


\section{A new urban paradigm for the Anthropocene - Regenerative}

\section{cities}

We suggest a successful city in the Anthropocene would be:

- Regenerative in that it would be capable of not only offsetting the high consumption patterns of conventional cities but will begin to regenerate parts of the biosphere that have already led to limits being exceeded, and

- Livable to ensure that the city continues to offer its opportunities for people to flourish, to provide citizens with security, health, culture and commerce.

Quality of life and livability have long been recognized as factors making cities competitive and attractive for investment and for citizens to create opportunities for their families and communities not available elsewhere. The Sustainable Development Goals (SDG's) are reflecting these livability visions (United Nations 2015b).

Regenerative cities are grounded within a restorative ecological world view (Girardet 2010), they require urban design, urban renewal and circular economy approaches that recognize cities as complex systems dependent upon the local bioregion. As explained below:

\footnotetext{
The road to regenerative urban development begins with a switch in our thinking so that byproducts conventionally considered "waste" can be reframed and reused as resource inputs.

Regenerative cities are productive centers that help to regenerate the materials and resources
} 
they use and foster a mutually beneficial relationship between urban areas and their surrounding territories (Woo 2014).

Cities are the dynamic centers of commerce and trade, so the sheer scale and volume of goods and material resource flows that they process make them the world's most complex "nexus" of social, political, economic and environmental systems (GIZ and ICLEI 2014). The material needs of cities are supplied by a vast national hinterland and, increasingly, by a global supply chain. The volume of consumption in most cities exceeds the rate at which the local bioregion and global biosphere can regenerate (Rees and Wackernagel 2008). Thus, the management of cities is no longer merely about maintaining a healthy economy to finance material purchases, but rather it must expand to include management of material resource flows and other environmental impacts, local and global whilst continuing to enable human flourishing.

Girardet (2010) states that cities will require comprehensive political, financial and technological strategies, grounded in a regenerative paradigm, in order to create an environmentally enhancing, restorative relationship between cities and the ecosystems from which they draw resources. A systems approach to urban development performance and management is needed to achieve this, but integrated approaches are not currently how most siloed government agencies and business structures are organized or funded (Brugmann 2011; GIZ and ICLEI 2014). No single agency is responsible for the urban agenda to coordinate 
development and sustainability (Fink 2011), and the role of civil society and industry can complement and accelerate sustainability policy.

A number of highly efficient integrated exemplars do exist that demonstrate technological capability to deliver not just sustainable development (reduced impact) but regenerative development (e.g. Europacity (Germany), BedZED (UK), Hammarby Sjöstad (Sweden)). However, the reality is that uptake of such initiatives is slow and proportionally small. Genuinely regenerative projects are rare and barely a tiny fraction of the global building stock. United Nations projections indicate a global population of 9.7 billion by 2050 (United Nations 2015c), if this projection is correct, it will be necessary to build approximately the equivalent of a city for one million every five days (Norman and Reid 2016). These high rates of urbanization coincide with recent changes in international policy direction that could help catalyze a rapid shift toward regenerative urban development.

\section{Changing international policy direction}

The primary impediment to widespread regenerative urban transitions is cultural (Lowe 2015). To emerge as a dominant cultural movement requires a strategic transition, a shift that changes culture: inevitably a long-term proposition according to Loorbach (2007). The narrative for cultural transitions has a long history; it is around 30 years since the publication of Our Common Future (United Nations 1987) but the announcement of the Sustainable Development Goals (SDGs) in September 2015 (United Nations General Assembly 2015) and the "Paris 
Agreement" (COP21) in December 2015 (United Nations 2015a) may mark the tipping point for a societal reframing of sustainability as the cultural mainstreaming of sustainability has deepened to a point where it is an imperative politically. However, the pathways to meet the objectives of these agreements are not clearly set out, so some possible mechanisms are offered below. Sustainable cities, can function as a central plank in addressing the grand challenges of climate change, resource scarcity and rapid population growth (Bai, Norman, and Edwards 2016) but the next agenda will require cities to go beyond this sustainability transition to being regenerative (Girardet 2015; Thomson and Newman 2016). This paper suggests how cities can scale up such urban transitions to become regenerative.

\section{Urban Transitions}

Considerable literature exists describing the negative impacts that large automobile dependent cities have in terms of sustainability (e.g., Newman and Kenworthy 1989, 2015; Newman 1999) and livability (e.g., Gehl and Rogers 2013; Matan and Newman, 2017). Our previous research explored how cities can work to harness the positive potential of urbanization in the Anthropocene to sequester carbon through a range of infrastructural measures (Thomson and Newman 2016). Central to this approach is the (infra)structural transition of cities away from automobile dependence (Newman and Kenworthy 1999, 2015; Newman and Kenworthy 2011). These infrastructural measures in turn require new governance systems to optimize urban systems to increase regenerative repair whilst also enhancing livability through more 
human centered urban design outcomes (Thomson and Newman 2016; Thomson, Newton, and

Newman 2016).

The two concepts of sustainability and livability, based upon the dominant urban and transport (infra)structures, are intertwined. A sustainable city can also be a more people friendly city - a city that fosters human flourishing. Community or industry leadership has resulted in exemplary sustainable districts such as BedZED, Vauban and various One Planet Community developments (Thomson, Matan, and Newman 2013), the goal is now to push these ideas into a deeply challenging arena of regenerative urbanism.

So how might it be possible to shift conventional urban planning and design practice, which typically deliver unsustainable development, to more sustainable practices and then to more regenerative practices? Strong governance will be necessary to shape such a transition. The New Urban Agenda, the SDGs, the Paris Agreement, all add policy thrust at a high level but implementation will be difficult unless it is grasped by communities as their agenda and by industry as an opportunity for commercial activity. There is no clear road map and difficulties arise because alternative futures are not systematically structured within existing regimes; rather, the dominant policy and industry actors tend to emphasize short- and mid-term outcomes due to political cycles, individual interests and public pressure (Loorbach 2010). Conflicting agendas and short termism have delayed sustainable urban transitions, and solutions are only just being sketched out for regenerative urbanism. Never the less there are some exemplars that demonstrate it is possible to be regenerative in terms of energy, water, 
food and biodiversity within cities (Woo 2014; Newman et al, 2017). But these examples are the exceptions rather than the rule. Most regenerative developments are rarely larger than the community and occasionally may be as large as a district; to shift from niche to mainstream requires a radical rethink of urban fabric.

\section{The transformative role of urban fabric}

The theory of urban fabrics (Newman and Kenworthy 1999, Newman, Kosonen and Kenworthy 2016) shows how transportation systems create city form and function. The ideas basically demonstrate how three dominant underlying transport infrastructures - walking, transit, and automobile-based urban fabrics - result in different urban morphologies with differing urban qualities including sustainability and livability performance. This analysis can now be applied to the regenerative urbanism agenda as it shows that there are deep and dramatic differences in the consumption patterns of the three fabrics and hence they can be a focus of how we can change in a deep and dramatic way to being regenerative in our cities. The difference between walking and transit fabrics is orders of magnitude less than that of automobile fabric in most cities (Thomson and Newman, 2017; Newman, Kosonen, and Kenworthy 2016)).

It is worth noting that the majority of urban areas within Australia were built post-1945 following large population growth (from 7.5 million in 1945 to 24 million in 2014 (ABS, 2014)), 
urban and transport planning over that period has faithfully followed Modernist principles,

\section{[INSERT Figure 1.]}

Figure 1: Perth's basic raw material demand in terms of three urban fabrics plus Technology and Construction Innovation (TCI) Source: Thomson and Newman 2017. 
It is expected that walking and transit urban fabrics have far less negative environmental impact (in most areas of resource consumption) than automobile fabric in all cities as the evidence on walking and transit fabrics being generically lower in energy use is powerful (Newman and Kenworthy 1989, 1999, 2015)).

The Perth study shows how the Modernist planning ideas that have perpetuated urban sprawl have resulted in a less sustainable urban form in a city where climate, culture and other variables remain the constant. It demonstrates how underlying values (the various transport and planning manuals of Modernism) can deliver different urban fabrics with different performance.

The larger footprint of sprawling automobile urban fabric displaces food producing agricultural land and ecologically valuable land to accommodate urban development as cities grow (Seto, Güneralp, and Hutyra 2012). While automobile dependent urban areas themselves are suboptimal due to: higher transport emissions (Newman and Kenworthy 1989); higher embodied energy and carbon emissions due to greater material volumes (Gardner and Newman 2013); additional costs due to increased infrastructure lengths and traffic congestion (Dodson and Sipe 2006; Trubka, Newman, and Bilsborough 2010); lower social interaction including increased social isolation due to lower population density (Buys et al. 2012), more obesity, increased road fatalities, and higher local air pollution levels (Ewing, Pendall, and Chen 2003), 
The inefficiencies of automobile fabric make it an inappropriate building block for the cities

\section{Incorporating regenerative design principles into urban planning}

Regenerative design principles can address many of the functional aspects of a city seeking to maximize human flourishing and livability whilst radically reducing ecological footprint. Additional principles to underpin urban governance for regenerative cities might include:

- Prioritize renewable energy and storage. Energy can become regenerative if the fuel used to build and operate buildings and build and run transport is renewable and is greater than is actually being consumed by the city and thus 
can be used to help power and fuel the surrounding bioregion. This is likely to occur through renewably-powered electric systems in buildings and transport as well as renewable-gas (Green and Newman, 2017; Newman et al 2017).

- Build integrated water systems. Water can be collected at source within a city, and grey water and black water can be recycled and used to help regenerate aquifers and water bodies in the bioregion (Gandy 2004; Nair et al. 2014). This can be done with current technologies (BioRegional 2009, 22-33).

- Consider waste as a resource. Waste can be reduced to very small amounts but not regenerated unless very large amounts of energy are used due to thermodynamic limitations. However, the return of carbon, phosphorus, nitrogen and other trace elements to surrounding soils in the bioregion can be achieved, for example, through compost systems at the local or neighborhood or even regional level (Newman and Jennings 2008).

- Maximize biodiversity and open space. Biodiversity can become regenerative if it is built into every part of the urban fabric, including the new technologies of green roofs and green walls. Bioregional needs for biodiversity can be assisted by the city with its different structural habitats and intensive human power (e.g. through gardening, urban agriculture and urban biodiversity conservation) (see Davison and Kirkpatrick 2013; Beatley 2009, 2011; Newman and Jennings 2008; Newman and Matan 2013; Newman 2014; Dramstad, Olson, and Forman 1996; Forman and Godron 1986; Soderlund and Newman 2015). 
- Integrate sequestration. Increasingly, the potential of sequestration

The question remains how can this be done on a scale that matters? The rest of this paper will set out some policy directions for governance at different scales that appear to provide the best options for achieving regenerative urbanism.

\title{
Transforming different scales of urban fabric
}

\author{
At any stage in a city's history the patterns of land use can be changed and opportunities \\ can be taken to transform the urban fabric. It is possible to greatly improve the regenerative \\ urban performance of low density areas within a city by rebuilding automobile urban fabric
}


with higher density transit and walking fabric that can service the surrounding car-based suburbs.

Different parts of the city present different opportunities and scale of impact when considering regenerative urban transition potential. These shifts may be described in terms of macro, meso and micro scales.

\section{Macro scale}

The macro scale takes in the whole urban area or large parts of a city region.

Historical patterns for car-based sprawl that emerged in the second half of the $20^{\text {th }}$ century can no longer be sustained, not simply from a sustainability perspective, but also from economic and social perspectives (Newman and Kenworthy 2015). So how can they be reimagined as part of a regenerative urbanism?

As cities grow and the mean exposure time to travel extends beyond a 30-minute commute (an hour a day) known as the Marchetti constant (Marchetti 1994), the urban system tends to become dysfunctional. This appears to be happening to automobile urban fabric across the world (Newman and Kenworthy 2015). The dysfunctional nature of cities tends to have the greatest negative impact in terms of lost productivity, stress and cost (related to fuel) on the 
citizens with the longest commute, who also tend to be from lower socioeconomic demographics (Dodson and Sipe 2006). Thus, changing cities to be less car dependent will improve their livability as well as their impacts on the planet.

Urban infrastructure can change this by improving travel times through mode changes and through land use change. In larger cities, the most efficient mode for travelling longer distances is rail, which is now faster than private vehicle travel times in most larger cities (Newman, Kenworthy, and Glazebrook 2013). However perhaps the most important element that can be created by bringing fast rail into automobile fabric is the provision of dense urban centers or TODs around stations which can create opportunities for local jobs, local services and local community not available in the privatized spaces of automobile city fabric. This is becoming even more possible with the new technology of 'local shared mobility' that can mean car-free areas around rail stations as demand-responsive services provide 'last mile' connections (Glazebrook and Newman, 2018).

In response, some larger cities are introducing planning policies that encourage the integration of land use planning and transport that can create such opportunities. This involves a shift from monocentric "hub-and-spoke" cities, with a central business district surrounded by dormitory suburbs, to polycentric cities with multiple activity centers (Moir, Moonen, and Clark 2014). To improve transport speeds and efficiency, polycentric city activity centers or TODs are often built around transit hubs such as heavy or light rail stations (Curtis and Scheurer 2010; 
Newman and Kenworthy 2011; Scheurer and Curtis 2008; Thomson, Newton and Newman, 2016). The demand for such centers is now so great it is possible to use private finance in land development to fund new rail lines deep into automobile dependent fabric.

Integrating transit and land use around urban finance.

In order to build such combinations of urban rail and TODs around stations that enable automobile fabric to be transformed, there is a need to enable urban finance to be redirected from primarily funding automobile fabric through high capacity roads to urban rail integrated with land development. Such an approach is outlined by Newman, Davies-Slate and Jones (2017) as the entrepreneur rail model and is the model used by Japan and Hong Kong to build rail lines. This approach recognizes that there is now a major demand both for new rail lines and new urban centres or TOD's that minimize automobile dependence. It suggests that only by tapping the ability of private enterprise to identify the best sites for urban redevelopment will it be possible to bring private capital such as pension funds into long term investment for the long-term future of cities. The model uses private capital to finance urban transformation but is best done in partnership with public planners who can identify the corridors that enable the most public good when provided with a rail and multiple TOD opportunities. The model permits low density areas to be transformed into high density public transport corridors, with "value capture" from the redeveloped sites to fund the adjacent rail infrastructure. Value 
capture is a tried and tested policy and has been successful in the delivery of infrastructure such

\section{Meso scale}

Meso scale development includes precinct (district or neighborhood) level development, which may involve housing and public infrastructure (e.g., roads, open space, utilities). Comprehensive precinct scale development may present the greatest opportunity for meeting regenerative urbanism and livability needs. This is because the precinct scale allows for the coordination and economic feasibility of shared eco-infrastructure - localized solutions versus centralized solutions are a major issue in future planning as many sustainability solutions, particularly infrastructure (e.g. distributed energy, sustainable transport, water sensitive urban design) are local in scale (Bunning et al. 2013; Green and Newman 2017; Newton et al. 2011; Rauland and Newman 2015). Infrastructure integration at the precinct scale can improve efficiencies and provide opportunities for a more holistic approach to urban environments (Newton 2014; Newton, et al. 2012). 
Precincts are also the scale of community and as such present the optimal scale for community involvement in shared decision making. Precincts can reduce long term operating costs, and importantly can grow a local green economy from the construction, management and maintenance of distributed eco-infrastructure to foster an engaged citizenry; it is even possible to see 'citizen utilities' emerging from the rapid growth of solar PV, batteries and blockchainbased Peer-to-Peer trading (Green and Newman, 2017).

Perhaps most importantly, in terms of delivery, the precinct is the scale at which land development takes place. Precinct scale development permits the integrated planning of buildings, open space and infrastructure, and as such is the ideal scale for shaping the quality of the built environment in terms of regenerative performance (Sharifi and Murayama 2013) and livability (Carmona et al. 2012).

The smaller scale of the precinct versus the city allows for greater planning control and community engagement through more focused governance and management to oversee development outcomes and to prototype new models and replicate those that are most successful.

Precincts are the building blocks of cities (Rohe 2009; Newton et al. 2011), as such, regenerative precincts can function as transitional, decentralized, semi-autonomous, cellular units. A city comprised of a series of semi-autonomous units is more resilient (as the risk of 
shocks are distributed across the network) and can incrementally work towards an aspirational

\section{Micro scale}

Micro scale, in the context of cities, relates to the piecemeal transformation of individual plots. Although important, this is the least effective means of transformation. However, if small transformations occur en masse, it may be possible to achieve massive small change that is capable of harnessing the collective power of many small actions (Campbell 2011). This has been observable in the remarkable growth of roof-top solar in recent years which is disrupting traditional grids and creating the possibility of micro-grids with peer-to-peer trading that can enable whole areas to be exporting green energy and hence becoming regenerative (Green and 
Newman 2017). The household solar photovoltaic revolution in Perth, Australia, shows that collectively household solar which in 7 years went from almost nothing to being $30 \%$ of household rooftops is now effectively the biggest power station in the state of Western Australia, and projections suggest this figure could grow to 50\% of rooftops by 2020 (Clover 2016). There are now periods when rooftop solar is producing more power than the base-load coal-fired power stations and hence a way forward to rapidly phasing them out is now appearing, without this being driven by a plan; it will need a continuing partnership between households who are buying the solar PV (and batteries for storage), precinct scale management and broader scale governance to ensure the grid is stable and available for everyone. This integration of governance scales illustrates the potential for one element of the regenerative city, renewable power, to become a model for how other elements can be demonstrated as well.

The distributed and decentralized nature of the internet can help such models flourish, be shared and replicated through such software technology as blockchain which are rapidly being adopted to provide shared, trustworthy information that can respond immediately to demand (Green and Newman 2017).

\section{Discussion of scales}

Each scale has its relative advantages and disadvantages. At the micro scale it is possible to have the greatest control over the product as it is usually in single ownership. It may be easier to deliver a regenerative building and there are examples, and models (e.g., the Living Building 
Challenge (2014)) that demonstrate how this can be done. Site planning at the micro scale is the typical model in many parts of the western world.

However, the opportunity for system integration greatly increases at the larger meso, and macro, scale. At the macro city scale, large transport infrastructure projects (e.g. urban rail) will have a very strong influence on the urban fabric that will develop around these infrastructures, which in turn influence regenerative urban performance and livability at all scales below it. Similarly, comprehensive precinct planning at the meso scale allows for the coordinated delivery of social infrastructure and distributed infrastructures to deal with transport, energy, water and waste.

The greatest potential for regenerative outcomes result from meso or macro scale urban development that accommodate growth within a city's existing footprint and can replace automobile urban fabric. Concentrating higher density urban growth in redevelopment areas around new urban rail can offset the need for fringe land to accommodate a city's population increase. The larger the scale of development (i.e. plot $<$ block $<$ precinct) the greater the opportunity to coordinate physical and social infrastructure and even incorporate new local distributed infrastructure such as solar energy, water sensitive design and waste recycling systems as part of transit oriented designs. 
While the macro-scale presents the greatest opportunity for rapid change, it is also the

\section{Management, maintenance and operation}

Delivery of new distributed regenerative-infrastructures will require new forms of urban governance including ongoing management and maintenance that collectively have the capacity to build a local green economy (Truffer and Coenen 2012; UNEP 2013). Regular monitoring of urban regenerative performance through the use of urban metabolism (resource 
inputs and waste outputs, see Thomson and Newman, 2017) as an analytical tool will help

Consistent measurements are not commonly used but they are required to provide a common lexicon for urban regenerative performance comparison and coordination (Fink 2011; Rauland and Newman 2015). However, this may change following the development of consistent urban regenerative measurements proposed by the International Standards Organization - Sustainable Development in Communities (ISO 2016) to enable comparison and rolling up of metrics, between jurisdictions and through the tiers of government. A standardized reporting structure will be essential for intercity and international knowledge sharing exercises such as those that now occur between cities involved in C40, 100 Resilient Cities and ICLEI.

Cities are always changing. Change may be slow in some cases, particularly when considering the underlying infrastructure of roads, rail and underground services. However, rapid urbanization, is putting pressure on some cities to redevelop. It is important that the right kind of development occurs. The new evidence of decoupling may indicate that a major change in global footprint could now be underway (Newman, 2017). New evidence from Shanghai and Beijing show that decoupling of GDP from car use is well underway as the new growth in mobility is around the Metro and the dense urban fabric associated with this (Gao and 
Newman, 2018). But to ensure this has any hope of becoming a powerful new mainstream trend will require the world's cities to operate under a new urban paradigm. To recast the trajectory of cities will require a major change in education, governance processes, planning practice and political leadership. This paradigm must be regenerative urbanism.

A regenerative urbanism requires integrated policy bundling, and ideally, the proliferation of supportive entrepreneurial models for governance and finance across a range of scales such as:

- value capture to fund public infrastructure (Newman et al. 2017),

- citizen utilities to provide power and other services (Green and Newman 2017) and

- local funding mechanisms to manage, monitor and maintain supporting regenerative-infrastructure and green enterprise initiatives (Rauland and Newman, 2015; Newman et al 2017).

Once underway it will require constant vigilance and system evaluation to ensure the required outcomes are happening.

For much of the past century Modernist planning paradigms have influenced planning policy based upon architectural fashion and market preference based on automobile urban fabric, but research indicates that as cities grow ever larger this is to the detriment, not only of environmental performance, but also livability (Calthorpe 2010; Carmona et al. 2012; Gehl and Svarre 2013; Jacobs 1989). Increasingly sophisticated flows of information, especially digital 
information, has the potential to help disseminate feedback to the right people in a timely

manner to support regenerative urban transitions and maintain or improve quality of life.

Local development decisions need to feed into larger regenerative city plans and a global network of regenerative cities if urbanization is to be harnessed as a potential solution to reduce, and then reverse an excessive ecological footprint.

\section{Conclusions}

The cumulative messaging of the Paris Agreement, the Sustainable Development Goals and the New Urban Agenda may herald a global shift in culture to help facilitate the delivery of more sustainable and resilient cities but this paper suggests it must go beyond this to produce regenerative cities. The transition towards this future oriented narrative of regenerative urbanism is only just beginning to be mapped out but there is enough evidence to believe it may be possible to achieve (Thomson and Newman 2016).

The use of evidence-based policy is critical to meeting the objectives of these high-level international policies. Evidence based policy should shape strong planning. As this paper has discussed, strong planning and monitoring of urban environments can shape more regenerative, productive and livable development outcomes. Hall (2013) refers to the "lost art of urbanism" as being at the heart of many urban issues and it would appear to be highly relevant to this new regenerative urbanism agenda. Strong planning does not imply that it should be dictated in a non-democratic way, it means having clear objectives that inform every step of the 
planning process and tapping the entrepreneurial and community-based local knowledge so critical at smaller scales of urban activity. The opportunity presented by strong planning is to enable the fundamentals of regenerative urbanism to inform the whole planning system. This is not unlike the way that Modernism and car-based planning infiltrated every area of planning to create the dominance of automobile urban fabric in most global cities; it is possible with 'peak car' that we are on the edge of a similar transformative urban change (Newman and Kenworthy 2015; Newman, Beatley and Boyer, 2017). Emerging trends discussed in this paper are showing potential demand that could create exponential changes.

The regenerative urbanism agenda will need to proceed at various scales in urban development. Precinct scale development can deliver regenerative outcomes because it permits a comprehensive approach to planning that allows for the integration of urban elements.

However, not all precincts are equal in their ability to demonstrate regenerative urbanism, even if they superficially appear so (e.g., have a similar density, look and feel). Performance metrics and indicators can be used to determine where best to focus attention for improvement and to identify the best exemplars from which to learn. Performance is strongly influenced by physical design including urban fabric, site layout and urban systems (e.g., transport, energy, water, waste, biodiversity) integration. Similarly, the other scales of physical design in cities also have an impact upon the livability of a place, from regional corridors to the whole of city perspective. Regenerative design of cities at all scales is critical to both their environmental performance and quality of life - both impact upon the ability of humans to flourish. 
To be successful in the risk nexus presented by the Anthropocene, cities and the

\section{Acknowledgements}

The Authors would like to thank the National University of Singapore, Asia Research Institute for the invitation and financial support to attend their March 2017 Workshop on Resilient Cities: Environmental Governance for Human Flourishing in Urbanising Asia and the Pacific, where the nucleus of this paper was developed. Thanks are also due to the peer reviewers for their thoughtful and constructive comments, which have been incorporated to the benefit of the final paper.

\section{References}

Bai X, Norman B, and Edwards P (2016) “Navigating through the Urban Ageø: Principles Navigating through the Urban Ageø: Principles and Innovations." Solutions 7(May): 55-62. Beatley, T (2011) Biophilic Cities: Integrating Nature Into Urban Design and Planning. Washington, D.C.: Island Press.

Beatley, T (2009) “Biophilic Urbanism: Inviting Nature Back to Our Communities and Into Our 
Lives." William \& Mary Environmental Law \& Policy Review 34(1): 209-38.

Bina O, Mateus S, Pereira P, and Caffa A (2016) “The Future Imagined: Exploring Fiction as a Means of Reflecting on Today's Grand Societal Challenges and Tomorrow's Options." Futures. http://dx.doi.org/10.1016/j.futures.2016.05.009.

BioRegional (2009) BedZED r: Toolkit Part II A Practical Guide to Producing Affordable Carbon Neutral Developments. London, UK.

Bonneuil C and Fressoz J (2016) The Shock of the Anthropocene: the Earth, history and us. London, UK. Verso.

Brugmann J (2011) Financing the Resilient City: A Demand Driven Approach to Development, Disaster Risk Reduction, and Climate Adaptation. Bonn, Germany.

Bunning J, Beattie C, Rauland V and Newman P (2013) “Low-Carbon Sustainable Precincts: An Australian Perspective." Sustainability 5(6): 2305-26. http://www.mdpi.com/2071$1050 / 5 / 6 / 2305 /$.

Burdett R and Sudjic D (2010) The Endless City: The Urban Age Project by the London School of Economics and Deutsche Bank's Alfred Herrhausen Society. London, UK. Phaidon Press.

Buys L, Snow S, van Megen K and Miller E (2012) “Transportation Behaviours of Older Adults: An Investigation into Car Dependency in Urban Australia." Australasian Journal on Ageing 31(3): 181-86.

Calthorpe P (2010) Urbanism in the Age of Climate Change. Washington, D.C.: Island Press.

Campbell K (2011) Massive Small: The Operating Programme for Smart Urbanism. London, UK: Urban Exchange.

- - - (2016) “Massive Small Declaration.” Massive small. London, UK http://www.massivesmall.com/declaration/ (November 25, 2016). 
Carmona M, Heath T, Oc T and Tiesdell S (2012) Public Places - Urban Spaces. London, UK:

City of Melbourne (2012) “Urban Forest Strategy: Making a Great City Greener 2012-2032.” : 68. https://www.melbourne.vic.gov.au/Sustainability/UrbanForest/Documents/Urban_Forest_ Strategy.pdf.

Clover, I (2016) “Western Australia's Rooftop Solar Now State's 'biggest Power Station.'” Reneweconomy. http://reneweconomy.com.au/western-australias-rooftop-solar-now-statesbiggest-power-station-27206/.

Crutzen, P (2002) “Geology of Mankind.” Nature 415(January): 23.

Curtis C and Scheurer J (2010) “Planning for Sustainable Accessibility: Developing Tools to Aid Discussion and Decision-Making." Progress in Planning 74(2): 53-106.

Davison A and Kirkpatrick J (2013) “Re-Inventing the Urban Forest: The Rise of Arboriculture in Australia." Urban Policy and Research 32(2): 145-62. http://www.tandfonline.com/doi/abs/10.1080/08111146.2013.832669.

Dodson J and Sipe N (2006) “Suburban Shocks๑: Assessing Locational Vulnerability to Rising Household Fuel and Mortgage Interest Costs." In 29th Australasian Transportation Research Forum, Gold Coast, Queensland.

Dramstad W, Olson J and Forman R (1996) Landscape Ecology Principles in Landscape Architecture. Washington, D.C.: Harvard University Graduate School of Design, Island Press, American Institute of Landscape Architects.

Ewing R, Pendall R, and Chen D (2003) “Measuring Sprawl and Its Transportation Impacts." Journal of the Transportation Research Board 1831:10 (3): 175-83.

Fink J (2011) “The Case for an Urban Genome Project: A Shortcut to Global Sustainability.” The 
Bridge, Linking Engineering and Society 41(1).

Fink J (2013) “Geoengineering Cities to Stabilise Climate.” Proceedings of the ICE - Engineering Sustainability 166(5): 242-48.

http://www.icevirtuallibrary.com/content/article/10.1680/ensu.13.00002.

Flannery T (2015) Atmosphere of Hope: Solutions to the Climate Crisis. Penguin Books Limited.

Forman R and Godron M (1986) Landscape Ecology. Wiley. New York, NY

Gandy M (2004) “Rethinking Urban Metabolism: Water, Space and the Modern City." City 8(3): $363-79$.

Gardner H and Newman P (2013) Reducing the Materials and Resource Intensity of the Built Form in the Perth and Peel Regions. Curtin University Sustainability Policy (CUSP) Institute. Perth, Australia.

Gehl J and Rogers R (2013) Cities for People. Island Press. Washington DC.

Gehl J and Svarre B (2013) How to Study Public Life. Island Press. Washington DC.

Girardet H (2015) Creating Regenerative Cities. Routledge. London, UK.

Girardet H (2010) Regenerative Cities. Hamburg, Germany. www.worldfuturecouncil.org.

GIZ and ICLEI (2014) Operationalizing the Urban NEXUS: Towards Resource Efficient and Integrated Cities and Metripolitan Regions. Eschborn, Germany.

Glazebrook G and Newman P (2018) “The City of the Future" Urban Planning 3(2): 1-20.

10.17645/up.v3i2.1247

Goa Y and Newman P (2018) “Beijing's Peak Car Transition: Hope for Emerging Cities in the 1.5 C Agenda" Urban Planning 3(2): 82-93. 10.17645/up.v3i2.1246

Gollagher M, and Hartz-Karp J (2013) “The Role of Deliberative Collaborative Governance in Achieving Sustainable Cities." Sustainability (Switzerland) 5(6): 2343-66. 
Green J and Newman P (2017) “Citizen Utilities: The Emerging Power Paradigm. A Case Study

Hajer M (2011) The Energetic Society. The Hague, The Netherlands.

Hall P (2013) Good Cities, Better Lives: How Europe Discovered the Lost Art of Urbanism. New York, NY: Routledge.

Hartz-Karp J (2007) “How and Why Deliberative Democracy Enables Co-Intelligence and Brings Wisdom to Governance How and Why Deliberative Democracy Enables CoIntelligence and." Journal of Public Deliberation 3(1). http://www.publicdeliberation.net/jpd/vol3/iss1/art6.

Inayatullah S and Milojević I (2015) CLA 2.0 Transformative Research in Theory and Practice. eds. S Inayatullah and I Milojević. Tamkang University Press. Taipai, Taiwan ISO (2016) INTERNATIONAL STANDARD Sustainable Development in Communities Management System for Sustainable Development. Switzerland.

Jacobs J (1989) The Death and Life of Great American Cities. New York, NY: Vintage.

Josh Byrne \& Associates (2016) WGV Waterwise Development Exemplar 2015 / 16 Partner Update.

Fremantle, Australia.

Landry C and Burke T (2014) The Fragile City and the Risk Nexus. Comedia Publications Limited. Stroud, UK.

Living Building Challenge (2014) "Living Building. A Visionary Path to a Regenerative Future." Living Building Challenge 3.0. A Visionary Path to a Regenerative Future. http://livingfuture.org/sites/default/files/reports/FINAL LBC 3_0_WebOptimized_low.pdf.

Loorbach D (2007) Transition Management: NewMode of Governance for Sustainable Development. Utrecht: International Books. 
Loorbach D (2010) “Transition Management for Sustainable Development: A Prescriptive, Complexity-Based Governance Framework." Governance, An International Journal of Policy, Administration, and Institutions. 23(1): 161-83. 10.1111/j.1468-0491.2009.01471.x.

Lowe I (2015) “Causal Layered Analysis, Climate Change and Limits to Growth.” In CLA 2.0 Transformative Theory in Research and Practice, eds. S Inayatullah and I Milojević. Taipei, Taiwan: Tamkang University Press, 109-22.

Matan A and Newman P (2016) People Cities. The Life and Legacy of Jan Gehl. Island Press. Washington, USA.

Marchetti C (1994) “Anthropological Invariants in Travel Behavior." Technological Forecasting and Social Change 47: 75-88.

McIntosh J, Trubka R and Newman P (2014) “Can Value Capture Work in a Car Dependent City? Willingness to Pay for Transit Access in Perth, Western Australia." Transportation Research Part A: Policy and Practice 67: 320-39.

http://www.sciencedirect.com/science/article/pii/S0965856414001736.

Mittal J (2014) “Self-Financing Land and Urban Development via Land Readjustment and Value Capture." Habitat International 44: 314-23.

http://linkinghub.elsevier.com/retrieve/pii/S0197397514001155.

Moir E, Moonen T and Clark G (2014) The Future of Cities: What Is the Global Agenda? London, UK.

Nair S et al (2014) “Water-Energy-Greenhouse Gas Nexus of Urban Water Systems: Review of Concepts, State-of-Art and Methods." Resources, Conservation and Recycling 89: 1-10. http://dx.doi.org/10.1016/j.resconrec.2014.05.007.

Newman, P., and I. Jennings (2008) Cities as Sustainable Ecosystems: Principles and Practices. 
Washington, D.C.: Island Press.

Newman, P., and A. Matan (2013) Green Urbanism in Asia: The Emerging Green Tigers. Singapore: World Scientific Publishing.

Newman P, Beatley T and Boyer H (2017) Resilient Cities: Overcoming Fossil Fuel Dependence, Island Press, Washington DC.

Newman P, Davies-Slate S, and Jones E (2017), The Entrepreneur Rail Model: Funding urban rail through majority private investment in urban regeneration, Research in Transportation Economics http://dx.doi.org/10.1016/j.retrec.2017.04.005

Newman P and Kenworthy J (1989) Cities and Automobile Dependence: An International Sourcebook. ed. Gower. Aldershot, UK.

- - (1999) Sustainability and Cities: Overcoming Automobile Dependence. Washington, D.C.: Island Press.

- - -(2015) The End of Automobile Dependence: How Cities Are Moving Beyond Car-Based Planning. Washington, D.C.: Island Press.

Newman P, Kenworthy J, and Glazebrook G (2013) “Peak Car Use and the Rise of Global Rail: Why This Is Happening and What It Means for Large and Small Cities." Journal of Transportation Technologies 3(4): 272-87.

Newman P, Kosonen L, and Kenworthy J (2016) “The Theory of Urban Fabrics: Planning the Walking, Transit and Automobile Cities for Reduced Automobile Dependence." Town Planning Reviews 87(4).

Newman P (1999) "Sustainability and Cities: Extending the Metabolism Model." Landscape and Urban Planning 44(February): 219-26. 
- - (2014) “Biophilic Urbanism: A Case Study on Singapore.” Australian Planner 51(1): 47-65. http://www.tandfonline.com/doi/abs/10.1080/07293682.2013.790832.

Newman P and Kenworthy J (2011) “Peak Car Use: Understanding the Demise of Automobile Dependence." World Transport Policy and Practice 17(2): 32-42.

Newton P, Newman P, Glackin S and Trubka R (2012) “Greening the Greyfieldsø: Unlocking the Redevelopment Potential of the Middle Suburbs in Australian Cities." World Academy of Science, Engineering and Technology 71(11): 658-77.

Newman P (2017) Decoupling Economic Growth from Fossil Fuels, Modern Economy, 8, 791-805. https://doi.org/10.4236/me.2017.86055

Newton P et al. (2011) AHURI Final Report Towards a New Development Model for Housing Regeneration in Greyfield Residential Precincts.

- - (2012) AHURI Research \& Policy Bulletin How Do We Regenerate Middle Suburban “ Greyfield "Areas ? Melbourne, Australia.

- - -(2014) “Regeneration: Tackling the Greyfields." In Creating Sustainable Precincts, ed. Tina Perinotto. Sydney, Australia: The Fifth Estate, 106-11.

http://evacoust.startlogic.com/TimeToyota.pdf.

Norman B and Reid J (2016) “In Quito, the World Meets to Discuss the Future of Cities." The Conversation (October): 1-4. https://theconversation.com/in-quito-the-world-meets-todiscuss-the-future-of-cities-67125.

Rauland V and Newman P (2015) Decarbonising Cities: Mainstreaming Low Carbon Urban Development. Springer International Publishing.

Rees W, and Wackernagel M (2008) “Urban Ecological Footprints: Why Cities Cannot Be 
Sustainable-and Why They Are a Key to Sustainability." Urban Ecology: An International

Perspective on the Interaction Between Humans and Nature 16: 537-55.

Rittel H and Webber M (1973) "Dilemnas in a General Theory of Planning." Policy Sciences 4(December 1969): 155-69.

Rockström J et al. (2009) "Planetary Boundaries®: Exploring the Safe Operating Space for Humanity." 14(2). http://pdxscholar.library.pdx.edu/iss_pub.

Roggema R and van Dobbelsteen A (2008) “Building Resilience: Responding to a Turbulent World." In UK Systems Society International Conference, Oxford, UK.

Rohe W (2009) “From Local to Global: One Hundred Years of Neighborhood Planning." Journal of the American Planning Association 75(2): 209-30.

Scheurer J, and Curtis C (2008) Spatial Network Analysis of Multimodal Transport Systems: Developing a Strategic Planning Tool to Assess the Congruence of Movement and Urban Structure. Perth, Australia.

Seto K, Güneralp B, and Hutyra L (2012) “Global Forecasts of Urban Expansion to 2030 and Direct Impacts on Biodiversity and Carbon Pools." Proceedings of the National Academy of Sciences of the United States of America 109(40): 16083-88.

Sharifi A and Murayama A (2013) “A Critical Review of Seven Selected Neighborhood Sustainability Assessment Tools." Environmental Impact Assessment Review 38: 73-87.

Soderlund J, and Newman P (2015) “Biophilic Architecture: A Review of the Rationale and Outcomes." AIMS Environmental Science 2(4): 950-69.

http://www.aimspress.com/article/10.3934/environsci.2015.4.950.

Steffen W et al. (2011) "The Anthropocene®: From Global Change to Planetary Stewardship." Ambio 40(7): 739-61. 
Steffen W, Richardson K, et al. (2015) “Planetary Boundaries: Guiding Human Development on a Changing Planet." Science 347(6223): 736-47.

Steffen W, Broadgate W, et al. (2015) “The Trajectory of the Anthropocene: The Great Acceleration." The Anthropocene Review 2(1): 81-98.

Steffen W, Crutzen J, and McNeill J (2007) “The Anthropocene: Are Humans Now Overwhelming the Great Forces of Nature?" Ambio 36(8): 614-21.

Thompson H and A Waugh (2009) A Process Revealed. FUEL Publ. London, UK

Thomson G, Matan A, and Newman P (2013) “A Review of International Low Carbon Precincts to Identify Pathways for Mainstreaming Sustainable Urbanism in Australia." In SOAC National Conference Proceedings, Nov 26-29 2013. Sydney, NSW: State of Australian Cities Research Network, Sydney, Australia.

Thomson G and Newman P (2016) “Geoengineering in the Anthropocene through Regenerative Urbanism." Geosciences 6(4).

- - - (2017) “Urban Fabric and Urban Footprint.” Resources, Conservation and Recycling. http://dx.doi.org/10.1016/j.resconrec.2017.01.010.

Thomson G, Newton P and Newman P. (2016) “Urban Regeneration and Urban Fabrics in Australian Cities." Urban Regeneration and Renewal 10(2).

TriMet (2015) 45 Years Making History and Transit in the Portland Region. Portland, Oregon.

Trubka R, Newman P, and Bilsborough D (2010) “Costs of Urban Sprawl (1) - Infrastructure and Transport." Environment Design Guide (83): 1-6.

Truffer B and Coenen L (2012) “Environmental Innovation and Sustainability Transitions in Regional Studies." Regional Studies 46(1): 1-21. http://www.tandfonline.com/doi/abs/10.1080/00343404.2012.646164. 
UNEP (2013) City-Level Decoupling Urban Resource Flows Urban Resource Flows and the Governance

of Infrastructure Transitions. A Report of the Working Group on Cities of the International

Resource Panel. A Report of the Working Group on Cities of the International Res. United Nations Environment Programme.

United Nations (1987) Our Common Future - Brundtland Report. New York, NY: Oxford University Press.

- - - (2014) Department of Economic and Social Affairs, Population Division World Urbanization Prospects: The 2014 Revision, Highlights. New York, NY. http://esa.un.org/unpd/wup/Highlights/WUP2014-Highlights.pdf.

- - -(2015a) 21930 Framework Convention on Climate Change "Adoption of the Paris Agreement" Adoption of the Paris Agreement. Paris, France.

http://unfccc.int/resource/docs/2015/cop21/eng/109r01.pdf.

- - - (2015b) Outcome Document of the United Nations Summit for the Adoption of the Post-2015

Development Agenda. Nairobi, Kenya.

- - - (2015c) Working Paper World Population Prospects: The 2015 Revision, Key Findings and Advance Tables. World Population Prospects.

- - - (2016) Habitat III New Urban Agenda. Draft Outcome Document for Adoption in Quito, October 2016.

United Nations General Assembly (2015) Transforming Our World: The 2030 Agenda for Sustainable Development. NY.

VisionPDX (2007) Portland 2030: A Vision for the Future. Portland, Oregon.

http://www.portlandonline.com/bds/index.cfm?a=195005\&c=46936.

Wiktorowicz J, Babaeff T, Breadsell J, Byrne J, Eggleston and Newman P (2018) “WGV: An 
Australian Urban Precinct Case Study to Demonstrate the $1.5^{\circ} \mathrm{C}$ Agenda Including

10

11

12
Multiple SDGs " Urban Planning 3(2): 64-81. 10.17645/up.v3i2.1245

Woo F (2014) Regenerative Urban Development. World Future Council. Hamburg, Germany. 
Basic Raw Materials of Three Different Urban Fabrics

Business as Usual (BAU) vs. Technology and Construction Innovation (TCI)

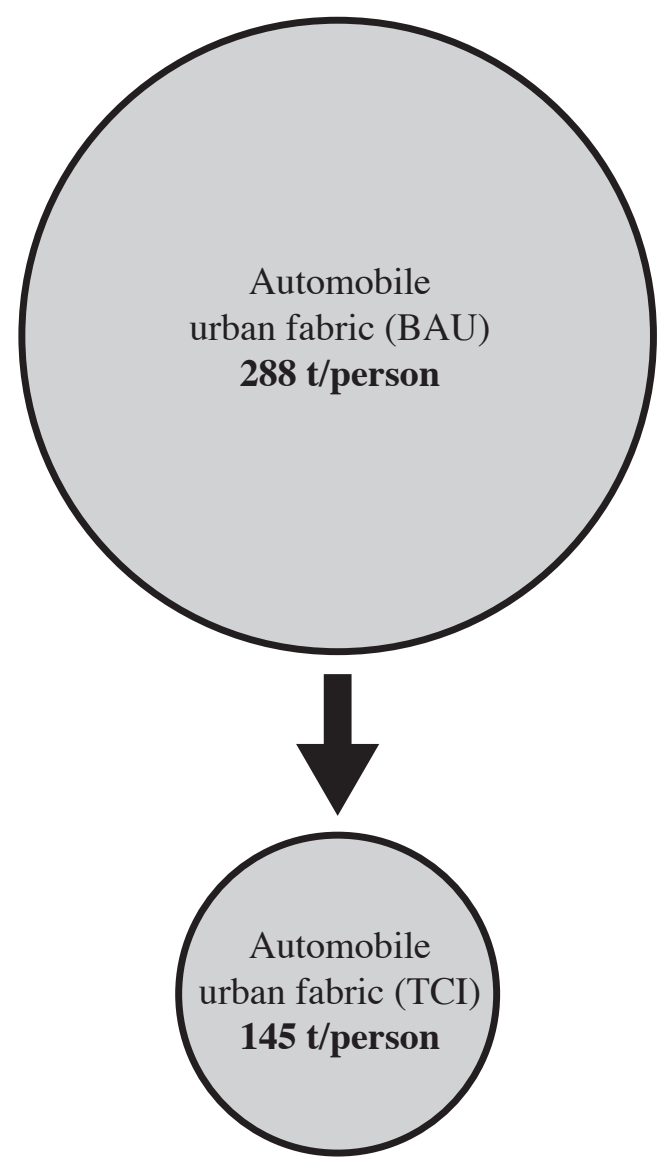

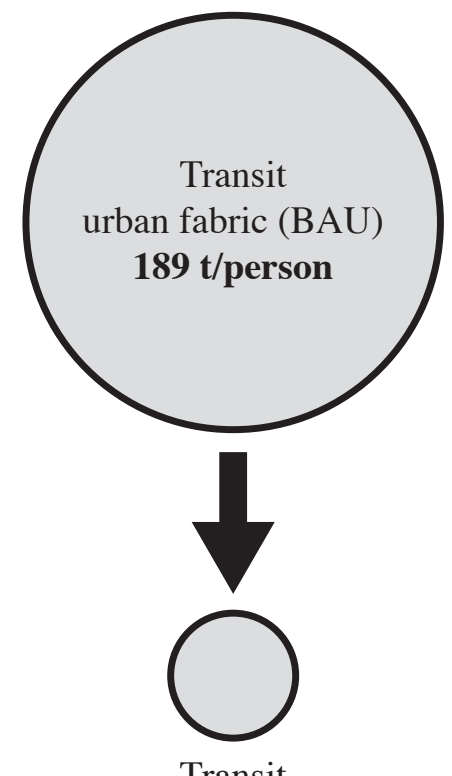

urban fabric (TCI) $57 \mathrm{t} /$ person

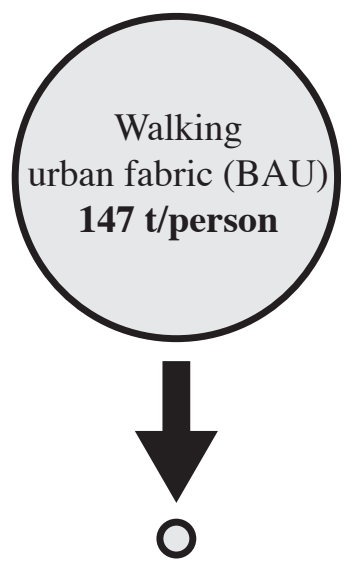

Walking urban fabric (TCI) $15 \mathrm{t} /$ person 